\title{
MOTIVASI DAN KETAHANAN BELAJAR MAHASISWA PENDIDIKAN JARAK JAUH: STUDI KASUS DI KEPULAUAN MALUKU
}

\author{
Benny Agus Pribadi, Lilian Sarah Hiariey \\ Universitas Terbuka (UT) Jakarta, Indonesia \\ Email: bennyp@ecampus.ut.ac.id, lilian@ecampus.ut.ac.id
}

Received: 2020-08-15; Accepted: 2020-08-05; Published: 2020-09-15

\begin{abstract}
Abstrak
Tujuan dari penelitian ini adalah untuk menggambarkan kegigihan miring peserta didik jarak jauh yang berdomisili di wilayah kepulauan Indonesia-pulau Maluku. 24 siswa pembelajaran jarak jauh yang tinggal di Pulau Maluku berpartisipasi dalam penelitian ini. Pendekatan kualitatif diterapkan dalam penelitian ini. Observasi dan wawancara jarak jauh digunakan untuk mengumpulkan data dan informasi yang diperlukan terkait dengan tingkat motivasi dan ketekunan belajar para peserta. Studi ini menemukan bahwa siswa pembelajaran jarak jauh yang tinggal di Pulau Maluku pada umumnya mengalami kesulitan dalam mendapatkan materi pembelajaran dan mempersiapkan ujian belajar mereka. Namun demikian, kurangnya fasilitas belajar tidak membuat ketekunan mereka yang condong rendah dalam mencapai harapan studi mereka. Dengan kata lain, mereka masih memiliki ketekunan dan motivasi belajar yang tinggi untuk menyelesaikan studi mereka di Universitas Terbuka (UT).
\end{abstract}

Kata Kunci: Pendidikan jarakjauh; motivasi; Ketekunan belajar

\begin{abstract}
The aim of the study is to describe the leaning perseverance of distance learners who domicile in archipelago areas of Indonesia - Maluku island. 24 students of distant learning who live in Maluku Island were participated in this study. Qualitative approach was applied in this present study. Observation and long-distance interview were used to collect required data and information related to the level of motivation and learning perseverance of the participants. The study found that the distance learning students who stay in Maluku Island in general have difficulties in getting learning materials and preparing their study exams. Nevertheless, the lack of learning facilities do not make their leaning perseverance low in achieving their study expectations. In other words, they still have high learning perseverance and motivation to complete their study in Universitas Terbuka (UT).
\end{abstract}

Keywords : Distance education; motivation; learning perseverance

\section{PENDAHULUAN}

Indonesia merupakan negara kepulauan dengan populasi penduduk lebih dari 250 juta jiwa. Negara kepulauan ini memiliki potensi sumberdaya alam dan sumberdaya manusia yang sangat luar biasa. Namun, perkembangan ekonomi yang tidak merata disetiap wilayah telah mengakibatkan munculnya masalah, yaitu tidak meratanya kualitas sumberdaya manusia yang ada di sejumlan wilayah di negara ini. Masalah ini sangat terkait dengan kondisi pendidikan yang ada di wilayah tersebut. Pada umumnya program pendidikan yang ada di wilayah terpencil di negeri ini hanya sebatas pendidikan pada tingkat menengah. Akses untuk mengikuti pendidikan tinggi belum menjangkau wilayah-wilayah tersebut (Cahyono, 2014).

Saat ini Indonesia memiliki sekitar 3000 perguruan tinggi, baik pemerintah maupun swasta. Dengan angka partisipasi kasar (APK) sekitar hanya 18\%, jumlah perguruan tinggi 
yang ada saat ini belum dapat memenuhi kebutuhan masyarakat untuk menggapai jenjang pendidikan tinggi. Upaya untuk meningkatkan APK tidak bisa dilakukan dengan mendirikan universitas dan institusi pendidikan tinggi konvensional. Salah satu upaya yang dapat dilakukan oleh pemerintah adalah dengan mendirikan universitas yang menerapkan sistem pendidikan terbuka dan jarak jauh seperti halnya Universitas Terbuka (UT) (Dikti, 2012).

Penyelenggaraan pendidikan tinggi dengan menggunakan sistem pendidikan terbuka dan jarak jauh memberikan beberapa keuntungan antara lain: (1) tidak memerlukan infrastruktur tanah dan bangunan untuk penyelenggaran program perkuliahan seperti halnya yang terjadi pada pendidikan tinggi reguler; (2) kebutuhan akan tenaga dosen dapat digantikan dengan memanfaatkan tenaga akademik bersama dan penggunaan media dan teknologi sebagai sumber belajar; (3) proses belajar mahasiswa dapat berlangsung secara flexible - tanpa ditentukan oleh faktor ruang dan waktu (Irianto, 2017).

Keberadaan UT sebagai lembaga pendidikan tinggi pemerintah telah diapresiasi oleh masyarakat. Hal ini dapat dilihat dari jumlah mahasiswa yang saat ini mencapai sekitar 350.000 mahasiswa. Dari jumlah tersebut mahasiswa yang mengikuti pendidikan guru saat ini mencapai tingkat 90 per sen. mahasiswa UT pada umumnya adalah mereka yang sudah bekerja dan memiliki keinginan untuk meningkatkan kualifikasi pendidikan dan kompetensi mereka. Penyelenggaraan sistem pendidikan di UT berbeda dengan sistem pendidikan yang diselenggarakan oleh perguruan tinggi konvensional, yang lebih menekankan pada proses pembelajaran tatap muka yang dilakukan secara reguler. Materi atau isi program perkuliahan yang diselenggarakan oleh UT lebih banyak disampaikan melalui penggunaan media dan teknologi pembelajaran atau instructional media and technology (Srianjani, 2020).

Masalah yang terkait dengan aktivitas pembelajaran pada umumnya dialami oleh mahasiswa yang berdomisili di daerah-daerah terpencil. Mereka sering mengalami keterlambatan dalam menerima bahan pembelajaran. Selain itu, mereka juga sering mengalami hambatan dalam hal keterbatasan sarana untuk melakukan aktivitas pembelajaran secara efektif dan efisien. Apakah kendala-kendala yang dihadapi tersebut mempengaruhi motivasi, kinerja dan ketahanan belajar mahasiswa khususnya yang berdomisili didaerah terpencil seperti halnya yang dialami oleh mahasiswa UT di Kepulauan Maluku? Penelitian ini dimaksudkan agar dapat menjawab pertanyaan tersebut diatas (Naim, 2021).

Penelitian ini bertujuan untuk mengetahui kendala-kendala yang dihadapi oleh mahasiswa dalam melakukan proses belajar dan dampaknya terhadap motivasi berprestasi serta ketahanan belajar yang dialami oleh mahasiswa UT yang berdomisili di daerah terpencil seperti kepulauan Maluku. Pemilihan kepulauan Maluku sebagai lokasi atau setting penelitian ini didasarkan pada kondisi geografis kepulauan tersebut yang terpisah dari kepulauan kontinen yaitu Ambon. Kondisi ini sangat berpengaruh terhadap kelancaran penyediaan fasilitas pembelajaran dan bantuan belajar bagi mahasiswa UT.

Penelitian ini bertujuan untuk mengkaji tentang kinerja, motivasi dan ketahanan mahasiswa yang berdomisili didaerah terpencil dalam mengikuti aktivitas pendidikan dan pembelajaran UT. Hasil penelitian ini diharapkan dapat menjadi bahan pertimbangan untuk meningkatkan kualitas pelayanan yang dapat diberikan oleh UT khususnya yang terkait dengan dukungan terhadap aktivitas pembelajaran terhadap mahasiswa yang berada di daerah terpencil. 


\section{METODE PENELITIAN}

Penelitian ini menggunakan pendekatan mixed method dengan memanfaatkan data kualitatif dan data kuantitatif untuk mengkaji fenomena yang akan diteliti - Motivasi dan Ketahanan Belajar Mahasiswa Pendidikan Jarak Jauh di Kepulauan Maluku. Penelitian ini bertujuan mengelaborasi aspek motivasi berprestasi dan aspek ketahanan belajar mahasiswa UT yang berada didaerah terpencil dalam hal ini Kepulauan Maluku. Data kualitatif dan kuantitatif yang diperoleh akan dianalisis untuk menjawab pertanyaan penelitian (Syahputra, 2019).

Penelitian ini melibatkan informan yang merupakan mahasiswa UT yang berdomisili didaerah terpencil khususnya Kepulauan Maluku. Pemilihan setting Ke[pulauan Maluku didasarkan pada jarak pulau-pulau yang terdapat di kepulauan tersebut yang sangat jauh dari wilayah kontinen-Pulau Ambon. Informan dipilih secara purposive untuk terlibat di dalam penelitian ini. Informan adalah mahasiswa UT yang berdomisili di sekitar kepulauan Maluku yang meliputi wilayah Piru, Kairatu Taniwel, Bula, Saumlaki, Dobo, Saparua, Langur, Kota Tual, Kisar dan Serwaru. Jumlah informan yang terlibat dalam penelitian ini adalah sebamyak 24 orang mahasiswa program studi keguruan dengan sebaran lokasi domisili yang berbeda.

Pengumpulan data dilakukan melalui penyebaran kuesioner, observasi oleh informan yang ditunjuk dan wawancara via telepon. Penyebaran Angket dilakukan untuk menjaring data dan informasi yang terkait dengan kesulitankesulitan yang dihadapi oleh mahasiswa dalam melakukan proses belajar dan mengakses bahan pembelajaran. Selain itu, pertanyaan-pertanyaan yang terdapat di dalam kuesioner juga dimaksudkan untuk mendapatkan data dan informasi yang berkaitan dengan ketahanan belajar mahasiswa dan motivasi belajar mereka selama menempuh perkuliahan di UT.

Observasi dilakukan oleh informan yang ditunjuk untuk memperoleh data dan indormasi yang diperlukan. Kegiatan observasi dilakukan bersamaaan dengan aktivitas tutorial tatap muka dan penyelenggaraan ujian (Sudihartono, 2020). Metode observasi dilakukan dengan tujuan untuk memperoleh data dan informasi yang terkait dengan cara belajar mahasiswa dan kesiapan informan dalam mengikuti program tutorial sebagai sarana bantuan belajar bagi mahasiswa UT.

Wawancara terhadap informan dilakukan dengan menggunakan saluran telepon. Hal ini dilakukan untuk melengkapi data dan informasi yang diperoleh melaui kuesioner dan pelaksanaan metode observasi. Wawancara dilakukan untuk menjaring data dan informasi tentang masalah belajar yang dihadapi oleh mahasiswa, cara menghadapi masalah belajar, dan ketahanan serta motivasi belajar yang dimiliki oleh mahasiswa selama mengikuti program perkuliahan di UT.

\section{HASIL PENELITIAN DAN PEMBAHASAN}

Analisis dilakukan terhadap data dan informasi yang diperoleh melalui instrumen pengumpulan data yang digunakan - observasi, wawancara, dan kuesioner. Data dan informasi yang berhasil dikumpulkan dianalisis dengan menggunakan pendekatan triangulasi. Pendekatan triangulasi dilakukan untuk memperoleh hasil yang komprehensif yang diharapkan dapat menjawab pertanyaan penelitian yang diajukan (Mulyadi, 2011). Hasil analisis data tentang motivasi dan ketahanan belajar mahasiswa pendidikan jarak jauh di kepulauan Ambon memperlihatkan bahwa:

Mahasiswa UT yang bermukim di kepulauan Ambon kerap mengalami masalah dalam hal memperoleh akses terhadap bahan belajar. Hambatan-hambatan yang kerap dihadapi 
oleh mahasiswa UT yang berdomisili didaerah terpencil pada umumnya berupa keterlambatan dalam memperoleh bahan pembelajaran atau modul yang diperlukan untuk mempelajari materi perkuliah. Jarak dan keterbatasan layanan transportasi di Kepulauan Maluku serta hambatan cuaca kerap mejadi faktor yang menyulitkan bagi mahasiswa untuk memperoleh bahan pembelajaran yang diperlukan secara tepat waktu. Masalah ini dapat membuat proses belajar mahasiswa menjadi tidak optimal.

Namun demikian, masalah keterlambatan ini dapat diatasi oleh mahasiswa dengan mencari bahan pembelajaran atau modul yang telah digunakan sebelumnya oleh kakak kelas atau senior mereka. Hasil observasi yang dilakukan terhadap sejumlah informan mahasiswa UT yang berdomisili di kepulauan maluku pada umumnya menggambarkan motivasi dan ketahanan belajar yang tinggi. Hal ini dapat dilihat dari perilaku ulet dalam melakukan belajar mandiri dan komitmen untuk memperoleh bantuan belajar pada waktu mengalami kesulitan dalam mempelajari isi mata kuliah.

Mahasiswa UT yang berdomisili di kepulauan Ambon pada umumnya memiliki ketahanan belajar atau learning perseverance yang tinggi. Mayoritas guru di kepulauan Ambon yang mengikuti program pedidikan dasar atau Pendas memiliki motivasi instrinsik yang kuat untuk menyelesaikan studi mereka di UT. Mereka memiliki semangat yang tinggi untuk melakukan proses belajar dalam upaya mengapai cita-cita untuk memiliki pengetahuan dan keterampilan yang diperlukan sebagai guru professional.

Hasil observasi dan wawancara yang dilakukan terhadap sejumlah informan mahasiswa UT yang berdomisili di kepulauan maluku pada umumnya menggambarkan motivasi dan ketahanan belajar yang tinggi. Hal ini dapat dilihat dari perilaku ulet mereka dalam melakukan aktivitas belajar mandiri dan komitmen untuk memperoleh bantuan belajar pada waktu mengalami kesulitan dalam mempelajari isi mata kuliah. Gambar berikut memperlihatkan mahasiswa S1 PGSD dan S1 PG PAUD yang berdomisili di wilayah kepulauan Maluku seperti halnya Dobo dan Saparua sedang mengikuti Ujian Akhir Semester

Walaupun memiliki beragam hambatan dalam menempuh program studi di UT, mahasiswa di kepualauan tetap memiliki komitmen yang tinggi untuk tetap melakukan aktivitas belajar sesuai dengan kalendar akademis yang dikeluarkan oleh UT. Dengan motivasi dan komitmen yang tinggi untuk mencapai cita-cita yang diharapkan. Informan juga memperlihatkan sikap disiplin yang tinggi dalam melakukan aktivitas dan proses belajar. Mahasiswa UT yang berdomisili di kepulauan Maluku memiliki motivasi intrinsik untuk meningkatkan kapabilitas dan kemampuan mereka.

Motivasi instrinsik berkaitan dengan keikhlasan dan kemauan untuk berkorban dalam mencapai cita-cita yang diharapkan (Uno, 2021). Motivasi belajar intrinsik ditunjukkan oleh mahasiswa kepulauan Maluku dengan cara melakukan kerjasama yang baik dalam melakukan proses belajar. Mereka pada umumnya tergabung dalam kelompok belajar yang mereka bentuk agar dapat memudahkan komunikasi jika mengalami hambatan dan kesulitan dalam menempuh program perkuliahan. Kelompok belajar yang terbentuk tersebut akan memudahkan mereka dalam mendiskusikan isi atau materi perkuliahan (Baedowi, 2015).

\section{KESIMPULAN}

Mahasiswa UT yang bermukim di kepulauan Ambon kerap mengalami masalah dalam hal memperoleh akses terhadap bahan belajar. Modul yang merupakan sarana belajar utama bagi mahasiswa UT kerap dperoleh terlambat. Masalah ini memberi dampak 
negatif terhadap proses dan aktivitas belajar yang dialami oleh mahasiswa. Namun demikian, Mahasiswa UT yang berdomisili di kepulauan Ambon pada umumnya memiliki ketahanan belajar atau learning perseverance yang tinggi. Mayoritas guru di kepulauan Ambon yang mengikuti program Pedidikan Dasar atau Pendas memiliki motivasi instrinsik yang kuat untuk menyelesaikan studi mereka di UT. Mereka memiliki semangat yang tinggi untuk melakukan proses belajar dalam upaya mengapai cita-cita untuk memiliki pengetahuan dan keterampilan yang diperlukan sebagai guru professional.

Walaupun memiliki beragam hambatan dalam menempuh program studi di UT, mahasiswa tetap memiliki komitmen yang tinggi untuk tetap melakukan aktivitas belajar dengan mengikuti kalendar akademis yang dikeluarkan oleh UT. Motivasi belajar dan komitmen yang tinggi untuk mencapai cita-cita yang diharapkan, diperlihatkan oleh informan melalui sikap ulet dan disiplin yang tinggi dalam melakukan aktivitas dan proses belajar.

\section{REFERENSI}

Baedowi, Ahmad. (2015). Calak Edu 4: Esai-esai Pendidikan 2012-2014 (Vol. 4). Pustaka Alvabet.

Cahyono, Edi. (2014). Manajemen Kebencanaan Berbasis Mahasiswa. Jurnal Bisnis, Manajemen, Dan Akuntansi, 2(2).

Dikti, Dirjen. (2012). Buku Panduan Sistem Pusat Karir. Dirjen Dikti.

Irianto, H. Agus. (2017). Pendidikan sebagai investasi dalam pembangunan suatu bangsa. Kencana.

Mulyadi, Mohammad. (2011). Penelitian kuantitatif dan kualitatif serta pemikiran dasar menggabungkannya. Jurnal Studi Komunikasi Dan Media, 15(1), 128-137.

Naim, Ngainun. (2021). Studi Islam, Mengajar Online, dan Mengajar tanpa Relasi Emosi.

Srianjani, Dewi. (2020). Properti Manten Tebu Sebagai Ide Penciptaan Motif Batik Busana Kebaya Pernikahan. Insitut Seni Indonesia (Isi) Surakarta.

Sudihartono, Yudi. (2020). Penerapan Quizizz Dalam Pelaksanaan Penilaian Pengetahuan Peserta Diklat Di Badan Pengembangan Sumber Daya Manusia Daerah Provinsi Sumatera Selatan. Jurnal Lentera Pendidikan Pusat Penelitian LPPM UM METRO, 5(1), 1-15.

Syahputra, Akbar. (2019). Studi Etnoagronomi Masyarakat Kabupaten Situbondo Serta Pemanfaatannya sebagai Buku Nonteks.

Uno, Hamzah B. (2021). Teori motivasi dan pengukurannya: Analisis di bidang pendidikan. Bumi Aksara.

(C) 2020 by the authors. Submitted for possible open access publication under the terms and conditions of the Creative Commons Attribution (CC BY SA) license (https://creativecommons.org/licenses/by-sa/4.0/) 